\title{
Reprinting of Kaba and Tambo Books by Kristal Multimedia Publisher
}

\author{
Nur Ahmad Salman Herbowo ${ }^{1}$, Sulastri ${ }^{2}$ \\ ${ }^{1,2}$ Universitas Andalas \\ e-mail: salman.herbowo@gmail.com ${ }^{1}$, sulastri.sasindo@yahoo.com²

\begin{tabular}{ccc}
\hline Diterima & Direvisi & Disetujui \\
$10-08-2020$ & $18-09-2020$ & $20-09-20$ \\
\hline
\end{tabular}

\begin{abstract}
This research uses Multimedia Crystal Publisher as a material object. The formal object is using the theory of literary sociology proposed by Robert Escarpit. The study of Escarpit's literary sociology is to analyze matters relating to the production, distribution and consumption of literary books. This study only at the stage of the production process (the process of re-publishing the Kaba and Tambo books). The existence of publishers has an important role in the preservation of folk literature in Minangkabau. Minangkabau folk literature presented with oral traditions is a consideration of the importance of printing the work into books. Minangkabau folk literature is a form of local wisdom in which there are values and philosophies of life from past historical and cultural events. So the current generation needs to know the stories contained in Kaba and Tambo. Publisher's work in reprinting classical literature is a form of efforts to save Minangkabau literature from extinction. Publisher Kristal Multimedia has republished two Tambo books and eighteen Kaba books, the results of which are printed and digital books (e-books). The work carried out by Crystal Multimedia publisher is a form of efforts to preserve literary works based on local wisdom.
\end{abstract}

Keywords: kristal multimedia publisher, kaba, tambo

Abstrak - Penelitian ini menggunakan Penerbit Kristal Multimedia sebagai objek material. Sedangkan untuk objek formalnya menggunakan teori sosiologi sastra yang dikemukakan oleh Robert Escarpit. Kajian sosiologi sastra Escarpit yaitu menganalis hal yang berkaitan dengan proses produksi, distribusi, dan konsumsi buku sastra. Namun dalam penelitian ini hanya pada tahap proses produksi (proses penerbitan ulang buku Kaba dan Tambo). Keberadaan penerbit memiliki peran penting dalam pelestarian sastra rakyat di Minangkabau. Sastra rakyat Minangkabau yang dihadirkan dengan tradisi lisan menjadi pertimbangan pentingnya untuk mencetak karya itu menjadi buku. Sastra rakyat Minangkabau merupakan bentuk kearifan lokal yang di dalamnya terdapat nilai dan filosofi kehidupan dari peristiwa sejarah dan budaya masa lampau. Sehingga generasi sekarang perlu untuk mengetahui kisah-kisah yang terdapat dalam Kaba dan Tambo. Kerja penerbit dalam mencetak ulang kembali sastra klasik tersebut merupakan bentuk upaya penyelamatan sastra Minangkabau itu dari kepunahan. Penerbit Kristal Multimedia sudah menerbitkan ulang tiga buku Tambo dan delapan belas buku Kaba, hasil terbitannya ada berupa buku cetak dan digital (e-book). Kerja yang dilakukan oleh penerbit Kristal Multimedia merupakan bentuk upaya melestarikan karya sastra berbasis kearifan lokal.

Kata Kunci: Penerbit Kristal Multimedia, Kaba, Tambo

\section{INTRODUCTION}

The development of technology and information contributed to language and literary research. Various results of language and literary research related to the influence of the development of media and information technology have emerged. In addition, the study of literature in tertiary institutions in accordance with the delivery of Faruk in public lectures can link literary science to the industrial revolution 4.0(Faruk, 2018). Of course it is a challenge for literary researchers at this time. Seeing the direction of the development of literary research that is no longer focused on the literary text, but has penetrated the context outside the text. The research included a number of studies of the literary community and the literature publishing industry.
Re-publishing Minangkabau literature is certainly an interesting thing to observe. The existence of Kristal Multimedia publisher has an important role in preserving Minangkabau literature. Folk literature presented with oral traditions takes into consideration of the importance of printing the work into book form. The presence of publishers is able to deliver classic literary works, some of which are difficult to obtain to the reader.

Kristal Multimedia Publisher is one of the literary book publishers in West Sumatra. The publisher specializes in the publication of Minangkabau literary books in the form of kaba, tambo, and pasambahan. Tambo is a historical literary work, a literary work that tells the history (origin) of the Minangkabau tribe, nation, and customs (Jamaris, 2002). While kaba is a rhythmic 
story, in the form of narration and classified as a long story (Jamaris, 2002). Pasambahan which is a kind of speech at a traditional ceremony in Minangkabau, such as the appointment of pangulu, can also be a negotiation between two parties(Amir, 2013).

It is undeniable that the publication of literary textbooks contributes to the preservation of literary works, especially classical literature whose existence can be said to be difficult to find. Classical literary works are also known as folk literatures which are delivered by oral tradition. Likewise in West Sumatra, as one of the regions in Indonesia with a unique culture and social system and has been proven in various historical, cultural, and social studies. The social system and cultural traditions of the Minangkabau people hold a lot of potential, including in the field of literature such as folklore. Oral traditions which are so strong for the habits of the Minangkabau people have an impact on the existence of folklore.

According to Djamarisinitially, the literature in the Minangkabau area was in the form of oral literature, that is, literature that was conveyed by word of mouth(Jamaris, 2002). Stories are memorized by storytellers or in the Minangkabau tradition referred to as kaba artisans kaba, by singing it to the listener. The stories presented in the Minangkabau folk literature are loaded with values of local wisdom and philosophy of life. Based on the meaning of Gegana Jayapada et al. (2017) local wisdom can be understood as a person's ability to behave or act by using his mind in the local area(Gegana, Faizol, and Kiptiah, 2017).

Minangkabau folk literature is a literary work based on local wisdom with stories presented in stories that are full of Minangkabau cultural values. Therefore, a study of the literary book publishing industry needs to be done by mapping and data collection of works that have been published, especially classic works that are full with local wisdom that have rarely been encountered. The purpose of this study is to see how local publishers such as Kristal Multimedia publisher have a role in the preservation of folk literature in their area (West Sumatra). To achieve this goal, a brief history of the existence of Kristal Multimedia publisher and the Minangkabau folk literature books presented in the form of kaba and tambo.

Some researches that conducted Escarpit's study of the sociology of literature, especially those related to the publication of local literature (regional literature), were the papers of I Nyoman Darma Putra and I Gde Nala Antara, namely "Challenges and Opportunities for Improvement of Modern Balinese Literature Book Publishing" in 2019 in Jurnal Kajian Bali(Putra \& Antara, 2019). There is also the thesis of Nur Ahmad Salman H in 2015 with the title "Literary Reproduction of Kristal Multimedia Publisher" in Indonesian Literature department at Andalas University(Salman, 2015). Then the Sri Sabakti paper "The Role of Publishers in Literary Development in Riau" in 2012 in the Madah Journal.

\section{RESEARCH METHODOLOGY}

This study uses a sociological approach to literature proposed by Robert Escarpit. The theory is put forward by Escarpit, that is literature which is the 'production' branch of the book industry, just as book reading is the 'consumption' branch of the industry (Escarpit, 2005). Looking at literature as a book, of course there are various kinds of activities and institutions that are between writers and readers.

The sociology of literature formulated by Robert Escarpit considers literature is no longer a cultural object, but is part of the product of modern industry. The views that make the most important elements of literary facts are books and book reading. The position of literature in society, for example, is not seen as limited to the author's biography as individuals and social phenomena contained in the work, but rather the collective nature and origins. This view explains the function of the publisher which was formulated by summarizing it into three verbs; choose, make (fabriquer), share(Escarpit, 2005). These activities are interrelated and form the overall cycle of the publisher's activities.

This study uses qualitative research methods, namely research procedures that produce descriptive data in the form of written or oral words from people and observable behavior(Moleong, 2014). Referring to the characteristics of qualitative research which are the findings of Bogdan and Biklen, as well as Lincoln and Guba, among them are the scientific setting, humans as tools, descriptive, and the existence of limits determined by focus(Moleong, 2014). These characteristics are found in this research process. Qualitative research techniques used were interviews, field notes, and document use.

\section{FINDING AND RESULTS}

\section{History of the establishment of Kristal Multimedia Publisher}

Kristal Multimedia Publisher at its inception was a company engaged in printing goods. Distribution of production results has reached Payakumbuh, Padangpanjang, and Padang. The 
initial name of the company from Kristal Multimedia Publisher was Balai Buku Indonesia. According to Salman, Balai Buku Indonesia began to become a company in 1982 in accordance with the deed of establishment of the company made by notary Achtar Iljas in Bukittinggi on July 15, 1982 No. 36 and in the form of limited partnership(Salman, 2015). A limited partnership or Commanditaire Vennootschap $(\mathrm{CV})$ is a company in which part of the company is only part of a certain amount of capital, while others are obliged to run the company(Pagaribuan, 1997).

Tabel 1: General Information of Kristal Multimedia Pubisher

\begin{tabular}{|c|c|}
\hline $\begin{array}{l}\text { Nama } \\
\text { Perusahaan }\end{array}$ & CV. Kristal Multimedia \\
\hline Pendiri & $\begin{array}{l}\text { AfrizalIndramaharajadanNielyar } \\
\text { Wisma }\end{array}$ \\
\hline BadanHukum & $\begin{array}{l}\begin{array}{l}\text { Persekutuan } \\
\text { (commanditairevennootschap }\end{array} \\
\text { atau CV) berdasarkanaktanotaris } \\
\text { Yul Faisal SH no.35 } \\
\text { tanggal 31 bulan } 5 \text { tahun } 2000 \text {. }\end{array}$ \\
\hline No. SIUP & 38/03-01/PM/VI/2006 \\
\hline Bidang Usaha & PercetakandanPenerbitanBuku \\
\hline $\begin{array}{l}\text { TerdaftarAngg } \\
\text { ota IKAPI }\end{array}$ & 01 Februari 2004 \\
\hline Alamat & $\begin{array}{l}\text { Jln. Mangga No. } 5 \text { TangahJua, } \\
\text { Kota Bukittinggi, Sumatra } \\
\text { Barat. }\end{array}$ \\
\hline Telp./ Fax & $(0752)-33768$ \\
\hline Email & indramaharaja@yahoo.com \\
\hline Website & $\begin{array}{l}\text { http://kristalmultimedia.blogspot.c } \\
\text { om } \\
\text { http://maharaja- } \\
\text { blogger.blogsopt.com } \\
\text { pendiri } \\
\text { perusahaan). }\end{array}$ \\
\hline AkunFacebook & Redaksi Kristal Multimedia \\
\hline
\end{tabular}

Along with its development, in 1985 the Indonesian Book Book Company began to develop its wings towards the book publishing industry. At the beginning of its production in publishing books, Balai Buku Indonesia only republished books that had been published by Pustaka Indonesia publisher. The first two books published by Balai Buku Indonesia are the Kaba Cindua Mato book written by Syamsudin St. Radjo Endah and Kaba Anggun Nan Tongga by Ambas Mahkota. The publication of these two books is due to the familial relationship between the owner of Pustaka Indonesia and Balai Buku Indonesia publisher. The relationship between the two is like the relationship between child and father. The owner of Balai Buku Indonesia Afrizal Indramaharaja is the son of the founder of Pustaka Indonesia, Zainuddin Mahyudin. In addition, Afirizal Indramaharaja has also worked at Pustaka
Indonesia publisher since attending junior high school.

The initial stages of the production of book publishing conducted by Balai Buku Indonesia did not experience any obstacles especially in the process of collaborating with the author. That is because of the good relations that have been undertaken by Pustaka Indonesia with its authors. By continuing this success and the principles of trust, some authors' families who are the heirs of the authors are happy to allow the book to be republished. As if they did not want to be overshadowed by the glory that was obtained by Pustaka Indonesia publisher, the two kaba books are published by Balai Buku Indonesia initially experienced many changes. In addition to the book cover design, paper selection, and the form of binding, the use of language was also one of the changes that occurred in both books. In the publication of Balai Buku Indonesia, the two kaba books are no longer use the Minangkabau language but rather the Indonesian language.

The translations that are conducted by Balai Buku Indonesia to the two kaba books apparently received a negative response from readers, especially readers who were outside of West Sumatra. According to Sudarmoko, this was due to the fact that the language used was not entirely correct(Sudarmoko, 2016). Many meanings are different from the original book written in the Minangkabau language. So that the two kaba books that have been circulating were withdrawn by the publisher and the selling is stopped.

Balai Buku Indonesia had a vacuum period and did not produce anymore. Many things caused the company to no longer operate, one of which was the employees who began to be busy with their own respective businesses. Those things could not be prevented by company leaders, because almost all employees are still in a family bond. Salman further explained the desire to recontinue the publishing and printing business of Balai Buku Indonesia arose when its founder, Arfizal Indramaharaja considered that at that time the availability of Minangkabau cultural reading materials in bookstores was minimal(Salman, 2015). He then made changes to the whole company. He started changing the organizational structure and replacing employees, renewing production equipment, and changing the company's name. This was done in order to provide new color and enthusiasm for the sustainability of the company.

Furthermore, Salman explained that the name of CV Balai Buku Indonesia was changed to CV Kristal Multimedia in accordance with Yul Faisal's notarial deed No. 35 on May 31, 2000 in Bukittinggi(Salman, 2015). That was the beginning 
of the name of the publisher Kristal Multimedia used. The name change has made the company have found a vision and mission, as well as a clear purpose in the publishing and printing industry. In addition, with the election of the founder of Kristal Multimedia publisher as Chairman of the West Sumatra Indonesian Publisher Association (Ikapi Sumbar), then Kristal Multimedia publisher's registration as a member of Ikapi in 2004 made the founder and leader of the book publisher become more serious in managing the company. This can be seen from the desire of its founder to focus the company in the field of printing and publishing special books on Minangkabau customs and culture. The first book was Kaba Cindua Mato and Anggun Nan Tongga in 2004.

\section{Reprinting Kaba and Tambo Books}

Speaking of literature can not be separated from the reality of the universe. Moreover, literature 'presents life', and 'life' consists largely of social reality, although literary works also 'mimic' nature and the subjective world of human(Wellek \& Warren, 1989). Therefore, the relationship of literary works with the community supporting cultural values cannot be separated, because literature presents life and consists mostly of social reality (society). With this understanding, it is undeniable that literary works have their own unique characteristics to the themes and stories that are presented based on the place where the work was born. Therefore, each region has traditional literature or also known as folk literature (oral).

West Sumatra as part of the archipelago which is rich in cultural diversity also has its own uniqueness including in terms of literature. According to Muhardi as is generally the literary works in the archipelago, in Minangkabau literature there are two kinds of forms of tradition, oral and written(Esten, 1988). In its essence, Minangkabau literature is oral literature, while Minangkabau written literature is only a transcription of oral literature. The strong oral culture in the life of the Minangkabau people also influenced the literary tradition in the area.

Broadly speaking, Djamaris classifies Minangkabau folk literature into three forms, namely poetry, prose, and drama(Jamaris, 2002). Djamaris further detailed this by dividing the types of literary works based on their form(Jamaris, 2002). Poetry in Minangkabau folk literature can be classified into several types, namely mantras, rhymes, Talibun, petatahs, and poetry. Then the type of Minangkabau literature classified as prose consists of carito, kaba, law, and tambo. While those included in the Minangkabau traditional drama group are randai and indang.
The existence of publishers have an important role in preserving folk literature found throughout Indonesia, including in Minangkabau. Folk literature presented with oral traditions must take into consideration of the importance of printing these works into literary textbooks. The presence of publishers are able to deliver the work of an author to the public, making novice writers or newcomers known to the public, and classic literary works (folk literature) some of which are difficult to obtain such as Minangkabau classical literature in the form of $k a b a$ and tambo which can be reprinted. This helps the community to obtain it, then reintroduces old writers and works, and maybe some of them are not well known by the public.

The work of publishers in reprinting classic literary works indirectly saves folk literature from extinction. The existence of Minangkabau folk literature today can be said to be in the worrying category, which is difficult to find people who know, memorize, and are able to convey it. In addition, the lack of millennial generation who want to relearn them and the strong flow of information technology development have changed people's lifestyles. All facilities offered by the times must be utilized in maintaining the existence of folk literature in Minangkabau.

The development of the times in terms of technology and information has become one of the alternative publishers in doing book publishing work. The publishing industry began to be born since the discovery of Guttenberg's printing press technology 500 years ago and now has entered the next stage of revolution with the invention of digital technology, especially computer technology and data communication networks via the internet, then the publishing industry which was originally conventional, will undergo fundamental changes(Taryadi, 1999). Quoting Winarno's statement regarding electronic publishing and publishing opportunities in the internet era, the development of information and communication technology also influenced the world of book publishing.

According to Winarmo in the beginning, digital technology was integrated into the publishing industry through the use of computerized computerized preprinted activities, so that the preprinted activities (editing, setting, lay-out, design, color separation) were practically no longer done manually, but in one integrated computer system(Taryadi, 1999). So that the book publishing process can be accelerated, and the productivity increases. However, now the computerized system carried out at the editing stage has entered into the publication. The development of information and communication technology has an impact on all sectors, including the book publishing industry. 
With the convenience presented by these developments, book publishing companies began to enter the realm of digital books, or commonly abbreviated with e-books. The form of the e-book is a book that is not in the form of paper, but in the form of data (softcopy). Some of the types of Minangkabau folk literature described by Djamaris above have already been published by Kristal Multimedia publisher. Until now, eighteen Kaba titles have been published and two of them are Tambo books.

Tabel 2: List of Published Kaba Books

\begin{tabular}{|c|c|c|}
\hline No & Nama Penulis & JudulBuku \\
\hline 1 & AmbasMahkota & $\begin{array}{l}\text { KabaAnggun Nan } \\
\text { Tongga }\end{array}$ \\
\hline \multirow{9}{*}{2} & \multirow{9}{*}{$\begin{array}{l}\text { Syamsudin } \\
\text { RadjoEndah }\end{array}$} & KabainduaMato \\
\hline & & KabaSitiBaheram \\
\hline & & KabaSitiKalasun \\
\hline & & KabaPutiNilamCayo \\
\hline & & Kaba Si GadihRanti \\
\hline & & $\begin{array}{l}\text { KabaLaksamana Hang } \\
\text { Tuah }\end{array}$ \\
\hline & & KabaSutanLembakTuah \\
\hline & & Kaba Si BuyuangKaruik \\
\hline & & $\begin{array}{l}\text { KabaTuankuLarehSimaw } \\
\text { ang }\end{array}$ \\
\hline 3 & Dt. PadukoAlam & KabaRancak Di Labuah \\
\hline \multirow{2}{*}{4} & \multirow{2}{*}{$\begin{array}{l}\text { M.Rasyid } \\
\text { Manggis }\end{array}$} & KabaMalinDeman \\
\hline & & KabaSabai Nan Aluih \\
\hline 5 & $\begin{array}{l}\text { SutanMangkudu } \\
\mathrm{n}\end{array}$ & KabaRambunPamenan \\
\hline 6 & $\begin{array}{l}\text { IlyasPayakumbu } \\
\text { ah }\end{array}$ & Kaba Si UmbuikMudo \\
\hline 7 & $\begin{array}{ll}\text { Darwis } & \text { St. } \\
\text { Sinaro } & \\
\end{array}$ & $\begin{array}{l}\text { KabaAngkuKapaloSitala } \\
n g\end{array}$ \\
\hline 8 & SutanNasarudin & KabaSitiRasani \\
\hline 9 & SutanPangaduan & KabaMagekManandin \\
\hline
\end{tabular}

Tabel 3: List of Published Tambo Books

\begin{tabular}{|c|l|l|}
\hline $\begin{array}{c}\text { No } \\
.\end{array}$ & \multicolumn{1}{|c|}{ Nama Penulis } & \multicolumn{1}{|c|}{ JudulBuku } \\
\hline 1 & $\begin{array}{l}\text { Ir. Edison danNasrun } \\
\text { Dt. Marajo Sungut }\end{array}$ & $\begin{array}{l}\text { Tambo } \\
\text { Minangkabau: } \\
\text { BudayadanHukumA } \\
\text { dat di Minangkabau }\end{array}$ \\
\hline 2 & $\begin{array}{l}\text { Ibrahim } \\
\text { DatoekSanggoenoDira } \\
\text { djo }\end{array}$ & $\begin{array}{l}\text { Tambo Alam } \\
\text { Minangkabau }\end{array}$ \\
\hline
\end{tabular}

Kristal Multimedia Publisher can be said to be one of the publishers who participated in using the facilities arising from the development of information and communication technology. At the end of 2014, precisely in December the publisher had begun publishing his books in the form of ebooks. It was intended that the books published could be owned by all people, especially those who were abroad. Many requests for books published by Kristal Multimedia especially kaba books from readers in Malaysia and the Netherlands caused the publisher to publish the digital version. With the digital version, readers who are far from where the publisher can get it through internet media. The internet is an international computer network system that is a product of research by the United States Department of Defense, which is ultimately left to the private sector to be managed independently(Taryadi, 1999).

All e-book versions of books published by Kristal Multimedia publishers have been uploaded to the Play Store. The ebook version of the book has no difference at all from the printed version in the form of content, the difference is only in the form of the form. The following books are in the e-book versions, such as Kaba Anggun Nan Tongga, Kaba Cindua Mato, Kaba Siti Baheram, Kaba Siti Kalasun, Kaba Puti Nilam Cayo, Kaba Si Gadih Ranti, Kaba Laksamana Hang Tuah, Kaba Sutan Lembak Tuah, Kaba Si Buyuang Karuik , Kaba Tuanku Lareh Simawang, Kaba Rancak Di Labuah, Kaba Malin Deman, Kaba Sabai Nan Aluih, Kaba Rambun Pamenan, Kaba Si Umbuik Mudo, Kaba Angku Kapalo Sitalang, and Kaba Siti Rasani. By following the times, the work of Kristal Multimedia publisher deserves to be appreciated. The presence of Minangkabau folk literature books both in print and digital versions has indirectly done work on preservation of local wisdom-based literary works.

\section{CONCLUSION}

Kristal Multimedia Publisher is one of the literary book publishers located in West Sumatra precisely in the city of Bukittinggi. The publisher specializes in the results of its publications in the form of Minangkabau folk literary books such as tambo, kaba, pasambahan books, and old Minangkabau saga. The publisher has published thirty two Minangkabau cultural books, thirty of which are Minangkabau folk literature books and two others are nagari (village) history books. As for Kaba there are eighteen books and Tambo there are two books. Kristal Multimedia Publisher also follows the development of information and technology media by presenting Minangkabau folk literature books in both print and digital versions. The publishing works carried out by these publishers have indirectly undertaken the work of preserving literary works based on local wisdom. 


\section{REFERENCES}

Amir, A. (2013). Sastra Lisan Indonesia. Andi.

Escarpit, R. (2005). Sosiologi sastra. Yayasan Obor Indonesia.

Esten, M. (1988). Menjelang Teori dan Kritik Susastra Indonesia yang Relevan. Penerbit Angkasa.

Faruk. (2018). Ilmu Sastra di Era Industri 4.0: Makalah Kuliah Umum. Master of Literature Study Program of Faculty of Humanities, Universitas Andalas.

Jamaris, E. (2002). Pengantar sastra rakyat Minangkabau. Yayasan Obor Indonesia.

Jayapada, G., Faizol, \& Kiptiah, B. M. (2017). Kearifan Lokal dalam cerita Rakyat Sebagai Media Pendidika Karakter untuk Membentuk Literasi Moral Siswa. Bibliotika: Jurnal Kajian Perpustakaan Dan Informasi, 1 No. 2, 60-62.

Moleong, J. (2014). Lexy, Metodologi Penelitian kualitatif, Penerbit PT. Remaja Rosdakarya Bandung.

Pagaribuan, T. (1997). Kamus Pergaulan. Pustaka Setia.

Putra, I. N. D., \& Antara, I. G. N. (2019). Tantangan dan Peluang Peningkatan Penerbitan Buku Sastra Bali Modern. Jurnal Kajian Bali, 09 No. 02, 475-498.

Salman, N. A. (2015). Reproduksi Sastra Penerbit Kristal Multimedia. Universitas Andalas.

Sudarmoko, S. (2016). Republishing Folktales: Their Audiences, Readers, and Influences in Modern Indonesian Literature. Kritika Kultura, 27.

Taryadi, A. (1999). Buku dalam Indonesia Baru. Yayasan Obor Indonesia.

Wellek, R., \& Warren, A. (1989). Teori Kesusastraan, terj. Melani Budianta. Jakarta: Gramedia. 